\title{
Providing Promotion Pathways That Reflect Changing Faculty Workloads
}

C. Scott Peters, University of Northern Iowa

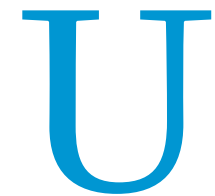
pon earning tenure, many faculty members find themselves adrift, unsupported by their institutions and unsure about how to take the next career step. Even as they enter "the stage in which most of their scholarly achievements occur and they assume important leadership and management roles in their institutions and disciplines" (Baldwin et al. 2008, 48), many do not take the most logical next step: promotion to professor. This often is viewed as an individual failure; stories of "dead-weight" faculty members and "stuck" associate professors abound. In this article, however, I argue that the failure is often an institutional one. Reflecting on my own experiences and reviewing the literature on mid-career faculty, I argue that universities do not adequately support the career development of post-tenure faculty and, by failing to reward the work that they increasingly ask faculty to do, have put roadblocks in the path to promotion to "full" professor. I argue that colleges and universities should support faculty members' development throughout their entire career path and should create pathways to promotion that recognize the changing nature of faculty work, properly rewarding people for the work that is important to the institution.

\section{WHAT COMES AFTER TENURE?}

I began my career with term appointments at three universities over five years, so getting a tenure-track job and earning tenure felt like confirmation that I had finally solved the puzzle of success in academia. Even so, I was unsure about what my next step should be. My department had clear criteria for tenure but offered only broad, vague standards for promotion to professor. So I reviewed the vitae of the department's three full professors, noticed that they had all written books, and set about writing a book.

Even before receiving tenure, though, I had begun to notice that the demands the university placed on me and my colleagues were changing. I was hired to teach three courses each semester, serve as academic adviser to 15 to 20 students, and be the coordinating pre-law adviser for the university. I also, of course, was expected to be a productive scholar and provide service to the university and community. The nature of the university's expectations for our teaching and research had begun to change subtly, however, and service demands had increased markedly. We were asked to help recruit students as state funding decreased and enrollment pressures increased; to integrate various "high-impact practices" into our teaching and advising in furtherance of the university's student-success goals; to consider various new teaching methods and pedagogies, including online teaching, flipped classrooms, and service learning; to seek ways to promote the university's goals of diversity and inclusion, and community engagement in our teaching and service; to be more entrepreneurial in seeking external grant revenues to fund research; to more quickly change curriculum in response to a rapidly changing economy; to find ways to expand growing, revenue-generating programs; and to fill a growing slate of committee appointments-often committees formed in response to demands from accrediting bodies, our governing board, the state legislature, and the federal government.

My progress on the book was interrupted significantly by these obligations, especially after I was elected to the faculty senate at a difficult time. I served as secretary during the year that the administration cut academic programs and dismissed faculty, resulting in a vote of no confidence in the president and provost, the president's resignation, and an American Association of University Professors investigation. I chaired the faculty senate the following year as we strengthened the faculty's role in shared governance, rebuilt trust between the faculty and the administration and board, and participated in a presidential search. After that, I served as chair of the faculty for two years. I found the work interesting and challenging and I felt that I was making a difference. Many colleagues praised my work, but I feared that the university did not value it where it counted most: in annual evaluations for merit pay or in promotion criteria.

As I met and talked to people across campus, I learned that many had similar experiences. I heard administrators lament the problem of stuck associates and the difficulty finding people to serve on committees. Meanwhile I heard faculty colleagues complain that the teaching, service, and outreach that they found fulfilling (and that the university claimed was central to its strategic goals) counted little toward promotion. Many colleagues avoided service altogether to focus on the scholarship that would count toward promotion. I also began to notice that the same people across campus tended to do much of the work on initiatives important to the university, that they often were women, that they were almost all excellent teachers, and that they were disproportionately associate professors. As I began planning to step back from service obligations to focus on my book, I used my remarks at the annual meeting of the university's faculty to call attention to this problem. I argued that the university's goals and priorities were misaligned with its incentive and reward structure. Aligning criteria for promotion and annual merit-pay incentives with the changing nature of faculty work, I argued, could 
liberate faculty members to do the work they find meaningful, provide stuck associates with multiple ways to advance their careers, and allow the university to more effectively advance its goals.

\section{ROADBLOCKS TO PROMOTION}

Because we think of promotion as an individual accomplishment, we too rarely "consider the institution's culpability for the roadblocks to faculty progression" (Mathews 2014, 5). and mentoring programs for the tenure track, they have only recently begun to recognize the need for a similar support structure for midcareer faculty (see, e.g., Wilson 2012 for a description of a program at Michigan State University and Buch et al. 2011 for a similar program at University of North Carolina-Charlotte; see also June 2018 for details about the University of Denver's mentoring-based post-tenure review system). This planning also can be complicated by standards for promotion to full professor that are more opaque than

\section{I heard administrators lament the problem of stuck associates and the difficulty finding people to serve on committees. Meanwhile I heard faculty colleagues complain that the teaching, service, and outreach that they found fulfilling (and that the university claimed was central to its strategic goals) counted little toward promotion. Many colleagues avoided service altogether to focus on the scholarship that would count toward promotion.}

Beaubouef, Erickson, and Thomas (2017) argued, however, that the career pathways that tenured professors follow are shaped by "the degree to which faculty needs and growth are taken up by the opportunities and rewards of their institutions" (Beauboeuf, as quoted in Flaherty 2017). In other words, "stuck associates" may be stuck not because they are not doing valuable work but rather because their college or university does not value and reward the work they do.

This helps to explain why the "feeling of relief [of getting tenure]...cedes quickly into a 'let-down" (Mathews 2014, 1) as faculty start to navigate new elements of their job without the benefit of the mentoring programs that they enjoyed as graduate students and tenure-track faculty members. Baldwin et al. $(2008,50)$ described this stage of the academic career as a "period of confusion and reassessment," with faculty members adrift as more work is piled on them. This combination of additional workload and lack of support results in high levels of job dissatisfaction. Using data from Harvard's Collaborative on Academic Careers in Higher Education (COACHE) survey, Mamiseishvili, Miller, and Lee (2016) reported that associates are less satisfied with many aspects of their job than either assistant or full professors and that their dissatisfaction grows the longer they are at the associate rank (Mathews 2014). These feelings appear to be distinct from midlife malaise more generally or from patterns of job satisfaction in other professions that, "like adrenaline shots for the career, [offer] more articulated opportunities for promotion" (Mathews 2014, 3-4).

Because the path to full professor often is not as clearly laid out as the tenure process, faculty must take it upon themselves to engage in career planning. According to Kerry Ann Rockquemore, president of the National Center for Faculty Development \& Diversity, faculty members must have an agenda lest they "just become part of everybody else's agenda" (Monaghan 2017; see also Buch et al. 2011 and Mathews 2014 on the importance of post-tenure career planning). Individual planning is not sufficient to address institutional deficits, however. Although many institutions have created support those for tenure (Baldwin et al. 2008; Buch et al. 2011; Fox and Colatrella 2006; Mathews 2014; Modern Languages Association 2009).

Finally, and most important, even when expectations for promotion are clear, they may not reward the full range of work that faculty do today. Trower $(2010,27)$ discussed the "...ratcheting up of expectations for all faculty" across all parts of their job. When the expectations for faculty work are not recognized and rewarded by the promotion system, some will avoid the work that goes unrewarded whereas others will become increasingly resentful that they are undervalued by their institution. When promotion criteria focus nearly exclusively on scholarship, even common institutional practicessuch as chairs assigning work to highly competent associate professors (which, as Baldwin et al. 2008 pointed out, might signal a vote of confidence from the chair)-make it more difficult for associates to focus on what they need to do to be promoted, which has consequences for careers. "Faculty who engage in labor that is critical but invisible in the reward structure, or who have been hurt through disparagement of their contributions and competences, are placed on pathways of reduced career satisfaction and weakened connection to the institution" (Beauboeuf, as quoted in Flaherty 2017). COACHE data indicate that $20 \%$ of associates have no plans to ever seek promotion (Mathews 2014).

Such dynamics enhance inequities. Someone will perform the increased service and outreach work that universities need. The questions then arise: Who does the work and are they properly rewarded and compensated for it? Too often in academia, the answers are "women and minorities" and "no." Several studies confirm the unequal balance of service placed on these colleagues and speak to its consequences on their advancement in the profession. Faculty members from underrepresented populations "are asked to serve more, advise more, show up more..." (Mathews 2014, 1; see also Baldwin et al. 2008). This unequal burden means that these faculty members perform the work that goes unrewarded, leaving other (disproportionately white and male) professors free to focus 
on the research that is rewarded (Buch et al. 2011; Lundquist and Misra 2015; Misra et al. 2011; Modern Language Association 2009; Perna 2001). Taking steps to equalize workloads across different types of faculty work would help this inequity (Perna 2001). However, I submit that although this is necessary, it is not sufficient. Institutions should move toward more "flexible and inclusive paths [to promotion] that recognize a broader range of contributions" (Buch et al. 2011, 40; see also Baldwin et al. 2008; Mathews 2014).
Third, it is possible to make incremental progress on these issues, and that progress can be used to push for more fundamental change. Discussions about tenure and promotion criteria, for example, started more than a decade ago on my campus. Many departments, including my own, found that clarifying our expectations not only made the process more transparent and equitable but also had an unanticipated benefit: focusing our efforts on what we do well and avoiding the "academic drift" (Berdahl 1985, 303) of trying to emulate the

\section{The questions then arise: Who does the work and are they properly rewarded and compensated for it? Too often in academia, the answers are "women and minorities" and "no." Several studies confirm the unequal balance of service placed on these colleagues and speak to its consequences on their advancement in the profession.}

\section{TOWARD A DIFFERENT SYSTEM}

During the past several years, my university has been moving toward a system that recognizes the changing nature of our work and evaluates faculty accordingly. As described previously, I played a minor role in calling attention to this and getting it on the agenda, but the difficult work has been done by colleagues active in United Faculty (UF), our faculty union. In collective bargaining about post-tenure review in 2015, UF proposed a system that revolved around the Boyer (1990) model of scholarship. Although UF and the administration did not reach agreement at that time, they formed a labormanagement working group to continue discussions. This work continued through more traditional shared-governance mechanisms after the Iowa legislature in 2017 stripped public employees' unions of their ability to bargain over workload. As of this writing, a faculty-administration committee's recommendations about new workload definitions have been added to the faculty handbook; its recommendations about new evaluation criteria are likely to be approved in the coming year. In keeping with our values and priorities as a comprehensive university, the new standard workload is $60 \%$ teaching, $25 \%$ scholarship, and $15 \%$ service. There is much that is still up in the air and there are many details to sort out. Ultimately, though, I think we will have a system that significantly improves the institution's ability to appropriately reward all of the important work that faculty members do.

Our experiences lead me to several suggestions about how other universities can move forward on these issues, as well as warnings about potential roadblocks. First, these conversations should begin with two simple questions: What does my institution claim it values? Do those claims match what it actually rewards? When it becomes more concrete to people that such misalignment has hampered their career development, they can start to talk to one another and move these issues higher up on the agenda. This leads to my second suggestion: personal stories matter. When faculty members talk to one another about their career goals and frustrations with their institution's lack of support, they build a base of support for change. more research-driven missions of larger universities. Similarly, one college within our university had already piloted a new pathway to promotion to full professor focused on applied research, so we had champions for new models even before the discussion began at the university level.

Most opposition has come from faculty rather than from administration, and it has centered on two concerns. First is the feeling that new pathways to promotion could cheapen the value of scholarship or otherwise alter the ability of faculty members to follow their research interests where they lead. The second objection focuses precisely on the scope of work that faculty are asked to do. Some fear that the new workload and evaluation criteria-rather than stopping the ratcheting up of expectations-will normalize or even increase the high demands on faculty time and effort. Both are powerful points that must be thoroughly discussed on any campus considering these changes. Responding to the first concern requires campuses to discuss a larger question: What does being a "full" professor mean? Is it a promotion that is reserved for distinguished and accomplished scholars, or is it a recognition of work-for all kinds of work-that has furthered the university's commitment to teaching, scholarship, and service? I argue that it should be the latter, and that both institutional interests and individual careers will be furthered and enriched if we so view it. To the second objection, my response centers on a sense that traditional emphasis on scholarship to the exclusion of other factors certainly has not stemmed the pressures increasing our workload. Too often, this has allowed some of our colleagues to avoid burdensome service work, creating the inequities discussed previously.

Institutional problems require institutional solutions, which may involve not only changing rules and processes but also challenging norms and institutional culture. The challenges, discussions, and solutions will vary across institutions. However, my review of literature suggests that many institutions (and the faculty within them) would benefit from pathways to promotion that support faculty career development and reward work that furthers all of the institution's goals and priorities. 


\section{ACKNOWLEDGMENT}

I thank Jennifer Diascro, Judith Grant, and Susan Sterett for organizing the National Science Foundation-sponsored workshop, "Advancement through Narrative: Understanding and Navigating Success and Failure in the Academy" (NSF Grant \#1643084), and the participants whose stories shaped my thinking on this issue as well as many other issues related to professional advancement within our profession.

\section{REFERENCES}

Baldwin, Roger, Deborah DeZure, Allyn Shaw, and Kristin Moretto. 2008 "Mapping the Terrain of Mid-Career Faculty at a Research University: Implications for Faculty and Academic Leaders." Change: The Magazine of Higher Learning 40 (5): 46-55.

Beaubouef, Tamara, Karla Erickson, and Jan Thomas. 2017. "Rethinking the Mid-Career Malaise." Unpublished research presentation. Available at www.aacu.org/sites/default/files/files/AM17/Mid-Career\%2oMalaise\%20 PPT.pdf.

Berdahl, Robert. 1985. "Strategy and Government: US State Systems and Institutional Role and Mission." International Journal of Institutional Management in Higher Education 9 (3): 301-7.

Boyer, Ernest L. 199o. Scholarship Reconsidered: Priorities of the Professoriate. Princeton, NJ: Princeton University Press.

Buch, Kimberly, Yvette Huet, Audrey Rorrer, and Lynn Roberson. 2011. "Removing the Barriers to Full Professor: A Mentoring Program for Associate Professors." Change: The Magazine of Higher Learning $43(6): 38-45$

Flaherty, Colleen. 2017. "Research on Midcareer Professors Makes Case for Support after Tenure." Inside Higher Ed. Available at www.insidehighered. com/news/2017/01/26/research-midcareer-professors-makes-case-supportafter-tenure (accessed May 10, 2018).
Fox, Mary Frank, and Carol Colatrella. 2006. "Participation, Performance, and Advancement of Women in Academic Science and Engineering: What Is at Issue and Why." Journal of Technology Transfer 31 (3): 377-86.

June, Audrey W. 2018. "Most Professors Hate Post-Tenure Review: A Better Approach Might Look Like This." Chronicle of Higher Education, February 11. Available at www.chronicle.com/article/Most-Professors-Hate/242483.

Lundquist, Jennifer, and Joya Misra. 2015. “The Clogged Pipeline.” Insider Higher Ed, July 20. Available at www.insidehighered.com/advice/2015/07/20/ essay-calls-new-metaphor-clogged-pipeline-academic-workforce.

Mamiseishvili, Ketevan, Michael T. Miller, and Donghun Lee. 2016. "Beyond Teaching and Research: Faculty Perceptions of Service Roles at Research Universities." Innovative Higher Education 41 (4): 273-85.

Mathews, Kiernan. 2014. Perspectives on Midcareer Faculty and Advice for Supporting Them. Cambridge, MA: The Collaborative on Academic Careers in Higher Education. Available at http://scholar.harvard.edu/files/kmathews/ files/coache_mathews_midcareerfaculty_20140721.pdf.

Misra, Joya, Jennifer Hickes Lundquist, Elissa Holmes, and Stephanie Agiomavritis. 2011. "The Ivory Ceiling of Service Work." Academe 97 (1): 22.

Modern Languages Association. 2009. "Standing Still: The Associate Professor Survey." Available at www.mla.org/About-Us/Governance/Committees/ Committee-Listings/Professional-Issues/Committee-on-the-Status-ofWomen-in-the-Profession/Standing-Still-The-Associate-Professor-Survey (accessed May 10, 2018).

Monaghan, Peter. 2017. "Helping Professors Overcome Midcareer Malaise." Chronicle of Higher Education. Available at www.chronicle.com/article/ Helping-Professors-Overcome/240009 (accessed May 10, 2018).

Perna, Laura W. 2001. "Sex and Race Differences in Faculty Tenure and Promotion." Research in Higher Education 42 (5): 541-67.

Trower, Cathy A. 2010. "A New Generation of Faculty: Similar Core Values in a Different World." Peer Review 12 (3): 27.

Wilson, Robin. 2012. "Why Are Associate Professors So Unhappy?" Chronicle of Higher Education. Available at www.chronicle.com/article/Why-AreAssociate-Professors/132071 (accessed May 9, 2018). 